\title{
The Effect of Temperature Variation on Water Scrubber System to Optimize Biogas Purification
}

\author{
Arief Abdurrakhman ${ }^{1}$, Dhirga Kurniawan², and Moch Machrus Adhim² \\ Department of Engineering Physics, Institut Teknologi Sepuluh Nopember, Surabaya, Indonesia \\ 1ariefabdurrakhman@gmail.com,2dhirgak@gmail.com, ${ }^{3}$ adhimmachrus@gmail.com
}

\begin{abstract}
Biogas is made from the anaerobic process, which methane $(\mathrm{CH} 4)$ as a primary element with some other elements. The composition of biogas in the experiment still contains $\mathrm{H} 2 \mathrm{~S}$ gas pollutants by $41,76 \mathrm{ppm}$. The amount of $\mathrm{H} 2 \mathrm{~S}$ content can reduce $\mathrm{CH} 4$ composition, so it has a lot of efforts to reduce $\mathrm{H} 2 \mathrm{~S}$ in biogas. One of them used water scrubber system, but the water scrubber system always changed according to the temperature ambient. It can cause inconsistency biogas quality, which is the reduction of $\mathrm{H} 2 \mathrm{~S}$ always changed. Another study showed that the speed of the water flow of 5.5 to 11 liters / min and water temperature of $10-25^{\circ} \mathrm{C}$, can reduce the $\mathrm{H} 2 \mathrm{~S}$ content in biogas up to $4.5-8 \%$, of the initial content by $37,8 \%$ to $43.6 \%$. So that is needed the design of water cooling system on purifying biogas. While this research aims that the lower water temperature will increase the effectiveness of the reduction of $\mathrm{H} 2 \mathrm{~S}$ with water temperature $15-20^{\circ} \mathrm{C}$. From the experiments that have been carried out test results obtained when the water temperature $20^{\circ} \mathrm{C}$ the content of $\mathrm{H} 2 \mathrm{~S}$ was $0.7 \mathrm{ppm}$ when the water temperature $17^{\circ} \mathrm{C} \mathrm{H} 2 \mathrm{~S}$ content was $0.6 \mathrm{ppm}$ when the water temperature $15^{\circ} \mathrm{C} \mathrm{H} 2 \mathrm{~S}$ was $0.5 \mathrm{ppm}$. Keywords - absorption; biogas; H2S; purification; water cooling system
\end{abstract}

\section{Introduction}

Gas purification greatly affects the quality of the biogas produced. The quality of biogas depends on the concentration of methane gas $\left(\mathrm{CH}_{4}\right)$ are contained. The higher of methane gas content in biogas, make the higher the quality of biogas, and vice versa. In addition, the quality of biogas can be improved by performing the purification of biogas, aim to reduce the levels of hydrogen sulfide $\left(\mathrm{H}_{2} \mathrm{~S}\right)$ and carbon dioxide $\left(\mathrm{CO}_{2}\right)$ [1]. Levels of $\mathrm{H}_{2} \mathrm{~S}$ contained in the biogas can be harmful to users because at high levels or more than $500 \mathrm{ppm}$ can cause lung damage and even lead to death [2]. So that is necessary purification process of biogas for an energy sustainability quality alternative, non-hazardous, and environmentally friendly.

In addition, the utilization of biogas for electrical purposes is still not used optimally. In a direct interview with Mr. Hariyanto (Consultant Biogas in Nongkojajar, Pasuruan Sub-District, East Java Indonesia), he said that the lack of biogas utilization as a source of electricity supply is caused by $\mathrm{H}_{2} \mathrm{~S}$ gas content are still relatively high, ranging from 40-45 ppm, while the minimum tolerance limit concentration of $\mathrm{H}_{2} \mathrm{~S}$ is $5 \mathrm{ppm}$ [3]. So that, a gas purification system is needed to produce more pure of biogas, i.e., with a high content of $\mathrm{CH}_{4}$, and $\mathrm{H}_{2} \mathrm{~S}$ content is low.
Currently, there are several biogas purification methods have been developed. There are absorption, adsorption, cryogenic, membrane, and carbon mineralization technology [4]. Literally, gas-liquid absorption method with water scrubber system is a priority in biogas purification applications, because its main ingredient is water can be relatively cheap and available, and environmentally friendly [5]. In water temperature of $10-20{ }^{\circ} \mathrm{C}, \mathrm{CO}_{2}$ gas solubility level between 2.5 to $1.6 \mathrm{~g}$ per $\mathrm{kg}$ of liquid gas. While at the same temperature value will be able to dissolve the $\mathrm{H}_{2} \mathrm{~S}$ gas at 5.5 to $3.9 \mathrm{~g}$ per $\mathrm{kg}$ of liquid gas [6]. One of the most widely used and economical is the incorporation of adsorption and absorption method, which biogas purification work using a water spray particles to bind water to gas impurities, including $\mathrm{H}_{2} \mathrm{~S}$ gas [1]. Biogas purification from acid gasses $\mathrm{CO}_{2}$ and $\mathrm{H}_{2} \mathrm{~S}$ using water scrubber reduced more $\mathrm{H}_{2} \mathrm{~S}$ than $\mathrm{CO}_{2}$ [7].

In this research will be optimized absorption of $\mathrm{H}_{2} \mathrm{~S}$ gas to the temperature in the biogas purification system with a water scrubber. It is known that the temperature ambient of water scrubber always changing, through mathematical modeling approaches will obtain the absorption of $\mathrm{H}_{2} \mathrm{~S}$ gas at the temperatures between 20$15^{\circ} \mathrm{C}$ of water scrubber plant in the area Nongkojajar Pasuruan Sub-District, East Java Indonesia. 


\section{Method}

\subsection{Water Scrubber}

Water Scrubber uses liquid fluid in the working process. Most of the fluid is water. This is the difference between Dry Scrubber with Wet Scrubber. The use of these fluids gives advantages to the system because it can control Scrubber Water-soluble gasses such as SOx, NOx, H2S, which in Dry Scrubber these pollutants cannot be controlled properly. Other advantages are due to the temperature control system Scrubber Water merged two different types of fluid temperature. Water for ways of working more efficiently than Dry Scrubber because it is able to capture particles as small and can bind gasses. The principle is to drain the liquid fluid in the flow of gas so instantly filtered by the liquid fluid [6].

\subsection{Reaction Equilibrium}

According to [4] absorption process of $\mathrm{H}_{2} \mathrm{~S}$ gas can be done with water $\left(\mathrm{H}_{2} \mathrm{O}\right)$. This method is considered very economical because it only uses water as raw material, which availability is very abundant. To do $\mathrm{H}_{2} \mathrm{~S}$ gas absorption optimization research needs to be done mathematical modeling. The aim of this mathematical modeling is to determine the objective function of the variables to be optimized.

The process of absorption of $\mathrm{H}_{2} \mathrm{~S}$ in biogas chemical reactions described in the following equation:

$$
\begin{gathered}
\mathrm{H}_{2} \mathrm{~S}_{(\mathrm{g})}+\mathrm{H}_{2} \mathrm{O}_{(\mathrm{l})} \leftrightarrow \mathrm{H}_{2} \mathrm{~S}_{(\mathrm{l})} \\
\mathrm{H}^{+}+\mathrm{HS}^{-} \leftrightarrow \mathrm{H}_{2} \mathrm{~S}_{(\mathrm{l})} \\
\mathrm{H}^{+}+\mathrm{S}^{2-} \leftrightarrow \mathrm{HS}
\end{gathered}
$$

According to the aspect of kinetics reaction, $\mathrm{H}_{2} \mathrm{~S}$ gas absorption by the absorbent solution can be categorized as a heterogeneous reaction that is gaseous and liquid [8]. Based on the equation 3, the obtained mass balance is accompanied by a chemical reaction as follows:

$$
\mathrm{A}+\mathrm{B} \leftrightarrow \mathrm{C}
$$

\subsection{Mass Balance}

According to William Nock et al., 2011, the mass transfer of data with the reaction can be determined using mass transfer scheme as Fig. 1 [9].

Based on the schematic of Fig. 1 it was mathematically obtained mass balance in gas, stating that the mass balance is accumulated in the gas or liquid phase to follow the following equation [9]:

$$
\text { Accumulation }=\text { input-output }- \text { reaction }
$$

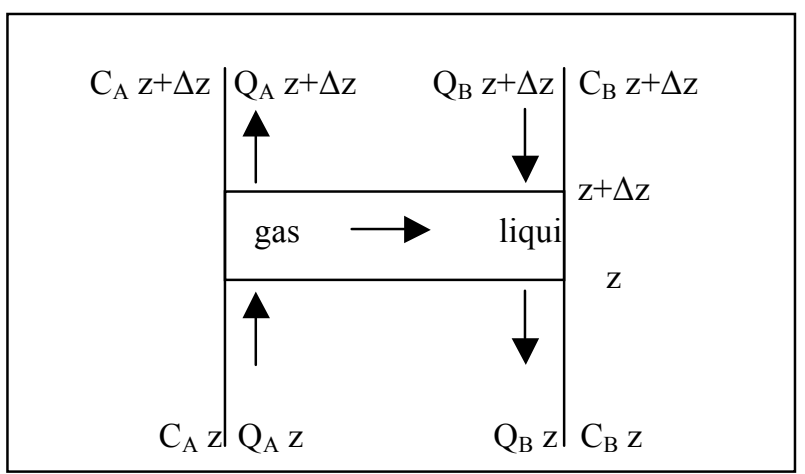

Fig. 1. Mass Transfer Scheme on Absorption Process.

\subsection{Solubility of $\mathrm{H}_{2} \mathrm{~S}$}

Reduction of $\mathrm{H}_{2} \mathrm{~S}$ officially has been made by some researchers. Fig. 2 shows the solubility model to the temperature of water [6]:

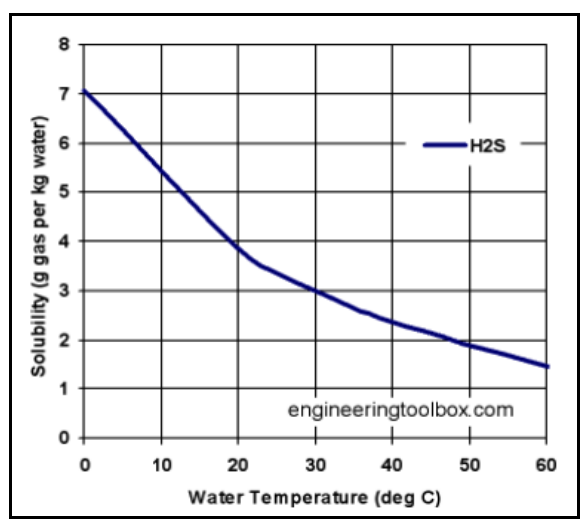

Fig. 2. The solubility of $\mathrm{H}_{2} \mathrm{~S}$ to Water Temperature.

\subsection{Design of Biogas Purification System}

This study proposed that the usage of water scrubber system with 4 temperature variations. $\mathrm{H}_{2} \mathrm{~S}$ content in biogas is measured at the input and output column purification. Biogas is used in the outcome of an anaerobic digester with base material cow dung. Anaerobic digester reactor types used concrete dome reactor (fixed-dome). Biogas reactor size used volume 8 $\mathrm{m}^{3}$. Plant of experimental study shown in Fig. 3.

\subsection{Efficiency of $\mathrm{H}_{2} \mathrm{~S}$ Absorption}

Through the $\mathrm{H}_{2} \mathrm{~S}$ gas concentration value, input and output are already known, the efficiency of absorption of $\mathrm{H}_{2} \mathrm{~S}$ gas can be known through calculation\% recovery by the following equation, [9]:

$$
\% \text { recovery }=\mathrm{H}_{2} \mathrm{~S} \text { output }: \mathrm{H}_{2} \mathrm{~S} \text { input }
$$

Percent recovery represents the amount of $\mathrm{H}_{2} \mathrm{~S}$ gas particles are absorbed by water scrubber. The higher of recovery value, make the better efficiency, vice versa. 


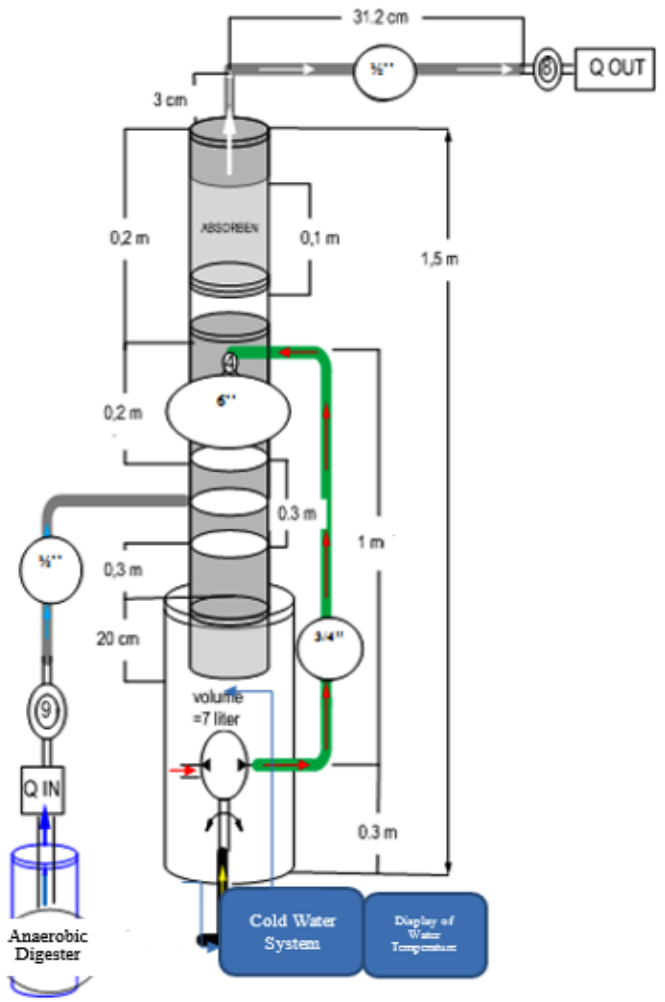

Fig. 3. The design of Biogas Purification System.

\section{Results and Discussion}

\subsection{Water Scrubber Temperature Effect to Reduce $\mathrm{H}_{2} \mathrm{~S}$ in Biogas}

Tool cooling design can hold as much water as $1,300 \mathrm{~L}$, and can cool the water in accordance with a predetermined set point of $15^{\circ} \mathrm{C}$, to cool the water in order to reach the setpoint can be found under the monitoring results are stored in a database of stored data required term time during 18 minutes. The main function of the cold water is to reduce gas impurities contained in biogas, especially $\mathrm{H}_{2} \mathrm{~S}$. In the cold water, the experiment has 3 different temperature variations. Here are the data obtained.

The mechanism of water temperature measurement using thermocouples connected to the microcontroller to run the pump and solenoid valve actuators automatically. When the cooling device operation, it will Peltier cool box filled with water for the purification process water scrubber system.

Table 1. The Effect Of Temperature To Reduce $\mathrm{H}_{2} \mathrm{~S}$

\begin{tabular}{|c|c|c|c|}
\hline No & $\begin{array}{l}\text { Tempera- } \\
\text { ture }\left({ }^{0} \mathrm{C}\right)\end{array}$ & $\begin{array}{c}\mathrm{H}_{2} \mathrm{~S} \\
\text { Measurement } \\
\text { Result }(\mathrm{ppm}) \\
\end{array}$ & Method \\
\hline 1 & 20 & 0.7 & \multirow{3}{*}{$\begin{array}{l}\text { Ionization Merk } \\
\text { Photovac Type } \\
2020 \text { ppb pro }\end{array}$} \\
\hline 2 & 17 & 0.6 & \\
\hline 3 & 15 & 0.5 & \\
\hline
\end{tabular}

The result of this research is a reduction of the optimum value of the $\mathrm{H}_{2} \mathrm{~S}$ which the water temperature in a water scrubber at $15{ }^{\circ} \mathrm{C}$, amounted to $98.7 \%$. Through the reduction of pollutant gas levels in this study, it could theoretically increase the level of methane in the biogas and methane content of the largest set of conditions in a water scrubber water temperature of $15{ }^{\circ} \mathrm{C}$. Results of testing the duration of the cooling process to achieve each set point are as follows: $\mathrm{T}=15^{\circ} \mathrm{C}$ for 60.6 seconds; $\mathrm{T}=$ $17^{\circ} \mathrm{C}$ for 61.1 seconds, and $\mathrm{T}=18{ }^{\circ} \mathrm{C}$ for 62.1 seconds.

\section{Conclusion}

The proposed water scrubber operation with cooling water was shown to be successful in the reduction of $\mathrm{H}_{2} \mathrm{~S}$ in biogas. The lower the temperature of the water in the water scrubber system, also increasing the reduction of levels of $\mathrm{H}_{2} \mathrm{~S}$. Through this $\mathrm{H}_{2} \mathrm{~S}$ reduction, then theoretically methane levels will increase and improve the quality of biogas.

Thanks to the family of authors, advisors, lectures, and all friends who supported this research. Without you maybe it was not successful.

\section{Notations}

$$
\begin{array}{ll}
\mathrm{A} & =\text { Surface absorber area, }\left(\mathrm{m}^{2}\right) \\
\mathrm{C}_{\mathrm{A}} & =\mathrm{H}_{2} \mathrm{~S} \text { gas concentration in liquid, }(\mathrm{ppm}) \\
\mathrm{C}_{\mathrm{Ai}} & =\mathrm{H}_{2} \mathrm{~S} \text { gas concentration in interface }(\mathrm{ppm}) \\
\mathrm{C}_{\mathrm{B}} & =\text { Concentration of } \mathrm{H},(\mathrm{ppm}) \\
\mathrm{C}_{\mathrm{C}} & =\text { Concentration of } \mathrm{S},(\mathrm{ppm}) \\
\mathrm{D} & =\text { Absorber diameter, }(\mathrm{m}) \\
\mathrm{G} & =\text { Biogas flow rate, }(\text { liter } / \text { minute })
\end{array}
$$

\section{References}

1. A. Abdurrakhman, M. M. Adhim, T. Ramadhan, ICAMIMIA, 86-90 (2015)

2. A. Noyola, J.M. Morgan-Sagastume, J.E. LópezHernández, Rev. Environ. Sci. Bio 5, 93-114 (2006)

3. A. Wellinger, A. Lindeberg, "Biogas upgrading and utilization," IEA Bioenergy, Task 24 : Energy from biological conversion of organic waste, Nova Energie GmbH.

4. M. O'Brien, Food Industry Environment Conference (1991)

5. W.M. Budzianowski, C.E. Wylock, P.A. Marciniak, Energ. Convers. Manage (2016)

6. L. Medard, Gas Encyclopedia (1976)

7. M. Islamiyah, T. Soehartanto, R. Hantoro, A. Abdurrahman, KnE Energy, 2 (2), 126- 131 (2015)

8. F. Osorio, J.C. Torres, Renew. Energ., 2164-2171 (2009)

9. W. Nock, S. Heaven, C. Banks, "Modeling water scrubbing biogas based technology," Promotion of Biogas Upgrading and Bottling in India and Europe Union, University of Southampton, 2013 